\title{
KAJIAN ASPEK VERNAKULARITAS PADA RUMAH KILUNGAN DI KOTA LAMA KUDUS
}

\author{
Anisa ${ }^{1, *}$ Ratna Dewi Nur'aini ${ }^{2}$ \\ 1,2 Jurusan Arsitektur, Fakultas Teknik, Universitas Muhammadiyah Jakarta,Jl Cempaka Putih Tengah \\ 27 Jakarta Pusat 10510 \\ *anisa@ftumj.ac.id
}

Diterima: 17-05-2020Ｄireview : 17-05-2020Ｄirevisi: 16-06-2020Ｄisetujui: 24-06-2020

\begin{abstract}
ABSTRAK. Kota Lama Kudus mempunyai karakteristik menarik dengan adanya tiga elemen yaitu menara, masjid, dan makam, yang ketiganya mempunyai daya tarik dan pengikat bangunanbangunan di sekitarnya. Rumah kilungan merupakan sebutan lokal rumah yang berada dalam satu lingkup dinding tinggi masif setinggi 3-4 meter, yang berisi rumah tradisional atau rumah gedong. Penelitian ini bertujuan untuk mengidentifikasi, mendeskripsikan, dan menafsirkan makna aspek vernakularitas rumah kilungan di Kota Lama Kudus. Penelitian ini menggunakan metode deskriptif kualitatif dengan studi kasus rumah di dalam kilungan di Kota Lama Kudus. Rumah Kilungan Kudus mempunyai susunan jogosatru, gedongan dan pawon. Keseluruhan material rumah kilungan terbuat dari kayu, digunakan pada kuda-kuda, dinding, gebyok, tiang, blandar, pintu dan jendela, kecuali pada lantai dan penutup atap.Tujuan utama rumah kilungan dibuat untuk melindungi barang dagangan yang tersimpan di dalam rumah. Latar sebagai pusat atau orientasi permukiman merupakan ruang terbuka yang dapat langsung terlihat ketika memasuki kilungan. Pada aspek budaya ditemukan keterkaitan antara bentuk rumah dengan aktivitas masyarakat yaitu mengaji dan berdagang, mempunyai pintu penghubung dengan tetangga meskipun tidak terdapat hubungan kekerabatan. Penempatan pintu masuk kilungan dari arah samping dan menuju ke latar ini dapat dimaknai bahwa rumah kilungan mempunyai privasi yang tinggi. Pada aspek lingkungan, Kota Kudus dikenal sebagai kota santri, bangunan utama dalam rumah kilungan menghadap selatan, mempunyai lahan memanjang utara-selatan, orientasi ke arah latar dan terdapat pintu masuk dari arah samping.
\end{abstract}

Kata kunci: Kilungan, Kota Lama Kudus, Latar, Material Kayu, Vernakular

ABSTRACT. Kudus Old City has a characteristic with the three elements of the tower, mosque, and tomb, which have the appeal and binding of the surrounding buildings. The kilungan house is a local design in a massive 3-4 meter high wall, which contains a traditional or gedong house. The objectives are to identify, describe, and interpret the meaning of vernacular aspects of the kilungan house in Kudus Old City. This research used a descriptive qualitative method with a case study of a kilungan house in Kudus Old City. Kilungan house has an arrangement of jogosatru, gedongan, and pawon. The house's entire material is made of wood, used on kuda-kuda, walls, gebyok, column, blandar, doors, and windows, except on the floor and roof coverings. Latar as the center or orientation of the settlement is an open space that can be directly seen when entering kilungan. In the cultural aspect, found the relation between the form of the house with community activities, especially praying and trading has a connecting door with neighbors even though there is no kinship. The entrance of kilungan from the side and towards the Latar can be interpreted as the kilungan house with high privacy. In the environmental aspect, the Kudus City is known as the city of santri. The main building in the kilungan house is south orientation, has a land stretching north-south, orienting towards the Latar, and there is an entrance from the side.

Keywords: Kilungan, Kudus Old City, Latar, Wood Material, Vernacular

\section{PENDAHULUAN}

Kota Lama Kudus atau yang sering dikenal dengan Kudus Kulon adalah sebuah kota Lama di Propinsi Jawa Tengah yang mempunyai landmark unik berupa Menara Kudus. Selain terkenal karena adanya Menara
Kudus, Kota Lama Kudus merupakan cikal bakal berdirinya Kota Kudus sekarang ini dan merupakan tempat berdakwah Sunan Kudus yang merupakan salah satu wali songo.

Secara arsitektural, Kota Lama Kudus ini sangat berkarakteristik disebabkan adanya beberapa elemen yang ada di pusat Kota 
Lama yaitu Menara Kudus sebagai Landmark, Masjid yang persis ada di samping Menara, dan Makam Sunan Kudus yang ada di belakang Menara. Ketiga elemen ini menjadi daya tarik dan pengikat bangunan-bangunan yang ada di sekitarnya. Penelitian pendahuluan yang sudah dilakukan dan dipublikasikan berjudul Karakteristik Arsitektur di Kota Lama Kudus menemukan beberapa hal antara lain, penataan kawasan di sekitar Masjid-Makam-Menara Kudus sangat dipengaruhi oleh letak elemen tersebut. Tidak ada satu bangunanpun yang menempel di Masjid Makam Menara Kudus. Tiga elemen penting ini diberi jarak walau hanya berupa gang sempit dengan bangunan yang ada di sekitarnya (Anisa, 2018).

Selain itu, secara arsitektural adanya rumah tradisional, rumah gedong, dan rumah kilungan menambah unik kawasan ini. Hal yang menarik untuk diteliti adalah dalam satu kawasan Kota Lama, terdapat 3 bentuk rumah yang masing-masing memiliki karakteristik tersendiri.

Rumah tradisional Kudus merupakan rumah tradisional yang unik karena adanya ukiran pada hampir seluruh bagian rumah. Rumah gedong, merupakan rumah khas yang ada di Kota Lama Kudus dan secara fisik lebih mirip dengan rumah eropa/indis. Rumah kilungan adalah rumah yang berada dalam satu lingkup dinding tinggi, dengan isi rumah bisa berupa rumah tradisional, dan bisa juga berisi rumah gedong.

Ketiga rumah tersebut mempunyai latar belakang kesejarahan yang berbeda-beda. Fokus yang akan diangkat pada penelitian ini adalah mengenai aspek vernakularitas dengan mengambil studi kasus pada rumah kilungan.

Penelitian ini bertujuan untuk: (1) mengidentifikasi dan mendeskripsikan aspek vernakularitas rumah kilungan di Kota Lama Kudus; dan (2) menafsirkan makna vernakularitas pada rumah kilungan di Kota Lama Kudus.

Penelitian pendahuluan tentang rumah kilungan dilakukan pada tahun 2003-2004 dengan fokus menafsirkan konsepsi dan susunan bangunan pada rumah di Dalam Kilungan di Kota Lama Kudus (Anisa, 2004).

\section{METODE PENELITIAN}

Penelitian ini menggunakan metode deskriptif kualitatif dengan mengambil studi kasus rumah di dalam kilungan yang ada di Kota Lama Kudus. Rumah kilungan adalah sebutan lokal untuk rumah yang berada di dalam pagar tinggi masif setinggi 3-4 meter.

Rumah kilungan secara umum dapat terbagi menjadi dua berdasarkan bentuk rumah yang ada di dalam lingkup pagar (kilungannya) yaitu yaitu kilungan rumah tradisional Kudus, dan kilungan rumah gedong. Penelitian ini mengambil studi kasus 3 rumah kilungan yang didalamnya berisi rumah tradisional Kudus, yang didasari oleh kondisi rumah tradisional Kudus yang semakin sedikit dan terancam punah.

Pengumpulan data primer dilakukan melalui observasi lapangan dan wawancara. Sedangkan data sekunder dilakukan melalui studi literature terutama berkaitan dengan penelitian-penelitian yang sudah dilakukan sebelumnya. Selain itu juga studi literatur digunakan untuk mencari pustaka berkaitan dengan arsitektur vernakular dan aspek-aspek vernakularitas.

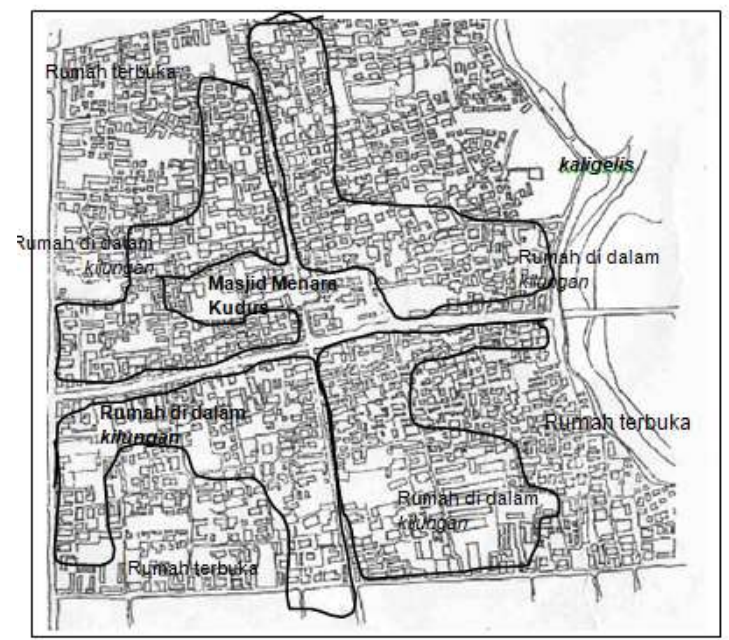

Gambar 1. Sebaran Rumah Kilungan (Sumber : Observasi Lapangan dan Anisa, 2004)

Materi yang dikumpulkan dalam penelitian ini adalah meliputi kondisi fisik dan kondisi non fisik rumah kilungan. Kondisi fisik meliputi bentuk bangunan, tata ruang, susunan bangunan, ornament dan material yang digunakan. Sedangkan kondisi nonfisik meliputi latar belakang sejarah, budaya, dan kondisi sosial kemasyarakatan yang berkaitan dengan rumah kilungan.

Proses analisis dilakukan melalui beberapa tahap, yaitu : (1) identifikasi dan deskripsi aspek teknis, budaya, dan lingkungan sebagai aspek vernakularitas pada rumah kilungan; (2) identifikasi dan deskripsi ranah fisik dan ranah 
abstrak berkaitan dengan tiga aspek vernakularitas; (3) Menafsirkan aspek-aspek vernakularitas tersebut pada ranah fisik dan abstrak rumah kilungan di Kota Lama Kudus.

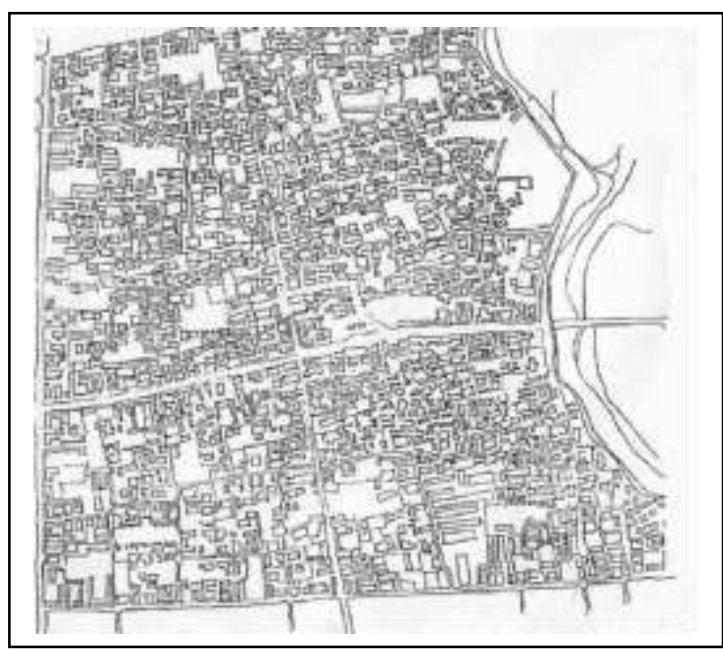

Gambar 2. Lokasi Penelitian Kota Lama Kudus (Sumber : Digambar ulang dari Wikantari \& Narumi, 1999)

\section{HASIL DAN PEMBAHASAN}

\section{Arsitektur Vernakular}

Arsitektur vernakular adalah arsitektur yang tumbuh dan berkembang dari arsitektur rakyat yang lahir dari masyarakat etnik dan berdasarkan pada tradisi etnik. Selain itu arsitektur vernakular juga dibangun berdasarkan pengalaman masyarakat setempat, menggunakan teknik dan material lokal serta merupakan jawaban atas kondisi lingkungan tempat bangunan tersebut berada. Arsitektur vernakular juga memungkinkan untuk terjadinya transformasi (Turan dalam Tarigan, 2016).

Rapoport mengungkapkan bahwa arsitektur vernakular dapat diartikan juga sebagai arsitektur yang lahir dari komunitas tertentu yang dibuat oleh dan untuk masyarakat atau kebudayaan tertentu (Rengkung, 2011).

Dapat disimpulkan bahwa arsitektur vernakular adalah arsiytektur yang memiliki sifat kelokalan atau lokalitas. Arsitektur vernakular juga bermakna sebagai arsitektur yang menyesuaikan iklim lokal, menggunakan teknik dan material lokal, dipengaruhi aspek sosial, budaya, dan ekonomi masyarakat setempat. Arsitektur vernakular juga dapat diungkapkan sebagai kesatuan antara bentukan fisik dan kandungan makna abstrak yang terwujud melalui teknis, dilandasi budaya dan dipengaruhi oleh lingkungan (Mentayani, et al, 2017).

Menurut Sumintardja (1981), arsitektur sebagai hasil karya manusia dipengaruhi oleh keadaan geografis, geologis dan iklim.

Warisan arsitektur vernakular Indonesia memiliki nilai karakteristik kuat sesuai dengan pemikiran komsologis dan pandangan hidup masyarakat asli. Hal yang penting untuk dimiliki arsitektur vernakular adalah nilai ekologis, yaitu sebuah nilai yang tanggap terhadap lingkungan dan mengacu pada potensi, kemampuan dan ketrampilan setempat, pengetahuan praktis, dan teknik tradisional (Wiranto, 1999).

Sekarang ini jumlah bangunan vernakular semakin berkurang, disebabkan banyak hal. Antara lain adalah bahan baku yang malah, perawatan yang relative mahal, dan pengetahuan yang kurang tentang struktur dan kostruksi bangunan vernakular (Prijotomo dalam Bagaskara \& Yusran, 2018).

Tidak hanya berkaitan dengan tata ruang, namun proporsi pada karya arsitektur vernakular juga sesuatu yang khas karena bisa ditentukan dari sebuah dasar ukuran bagian tertentu pada bangunan vernakular misalnya proporsi menggunakan proporsi pada tubuh manusia (Sani, dkk. 2015).

\section{Aspek Vernakularitas}

Pembahasan tentang aspek vernakularitas disarikan dari Mentayani et al. (2017).

Aspek vernakularitas dapat dibagi atas 3 hal yaitu aspek teknis, aspek budaya, dan aspek lingkungan yang ketiganya dapat berada di sisi ranah maupun unsur.

Aspek teknis merupakan hal-hal yang dapat diamati secara fisik, misalnya struktur, konstruksi, material dan bahan serta proses pengerjaanya.

Aspek budaya berkaitan dengan semangat dan jiwa yang terkadung di dalam fisik bangunannya. Sedangkan aspek lingkungan berkaitan dengan kondisi lingkungan dimana bangunan itu berada. Lingkungan dan budaya saling berkaitan membentuk arsitektur vernakular.

Tiga aspek pembentuk vernakularitas yang ada dalam ranah fisik dan abstrak selalu hadir dalam desain arsitektur vernakular walaupun 
dengan bobot yang berbeda. Jika salah satu tidak ada maka nilai vernakularitas menjadi tidak muncul (Mentayani et al., 2017).

\section{Proses Terbentuknya Rumah di dalam Kilungan}

Rumah kilungan adalah sebutan masyarakat setempat untuk menunjukkan rumah yang berada di dalam pagar tinggi. Pagar tinggi yang dimaksud adalah pagar dinding massif dengan ketinggian bervariasi antara 3-5 meter. Pagar tinggi pada rumah kilungan inilah yang membuat permukiman di kawasan Menara Kudus unik karena jalan-jalan kecil seperti lorong terbentuk dari tembok kilungan. Permukiman yang ada di Kota Lama Kudus mempunyai sebuah pusat yang diwujudkan dalam Menara Kudus. Menara Kudus tidak hanya sebagai pusat kegiatan di sekitarnya melainkan juga sebagai pusat dalam permukiman. Di sekitar menara Kudus inilah banyak terdapat rumah kilungan.

Pada saat membangun rumah tunggal di dalam kilungan, konsep adanya pusat dalam permukiman kembali diterapkan. Penerapan konsep tersebut adalah dengan tetap dipertahankannya latar yang merupakan orientasi bangunan di dalam kilungan. Perkembangan yang kemudian terjadi dengan semakin berkembangnya perekonomian, bangunan yang ada di dalam kilungan menjadi bertambah. Ternyata latar sebagai perwujudan pusat masih dipertahankan. Di dalam benak masyarakat kota Lama Kudus, latar adalah elemen yang merupakan perwujudan dari 'pusat' atau orientasi permukimannya (Anisa, 2004).

\section{Aspek Vernakularitas pada rumah Kilungan}

Aspek vernakularitas yang menjadi pokok bahasan meliputi aspek teknis, aspek budaya, dan aspek lingkungan. Ketiga aspek tersebut dilihat dalam dua ranah yaitu ranah fisik dan abstrak. Identifikasi yang sudah dilakukan mendapatkan hasil penafsiran yang dapat dijabarkan pada bagian bawa ini.

Aspek teknis di ranah fisik dan abstrak pada Rumah Kilungan yang diamati berupa bentuk kilungan, bentuk bangunan dan tata bangunan dalam kilungan beserta dengan material yang digunakan.

Aspek budaya di ranah fisik dan abstrak pada rumah kilungan yang diamati berupa perletakan jalan masuk, hubungan kekerabatan, dan perdagangan di dalam rumah kilungan.

Aspek lingkungan di ranah fisik dan abstrak pada rumah kilungan yang diamati berupa arah hadap bangunan terhadap kondisi lingkungannya, objek orientasi dan respon terhadap pergerakan matahari.

\section{Identifikasi dan Deskripsi Aspek Teknis}

Pada identifikasi aspek teknis dari tiga studi kasus rumah kilungan didapatkan bahwa ketiga rumah kilungan tersebut mempunyai kilungan berupa tembok masif setinggi 4-5 meter.
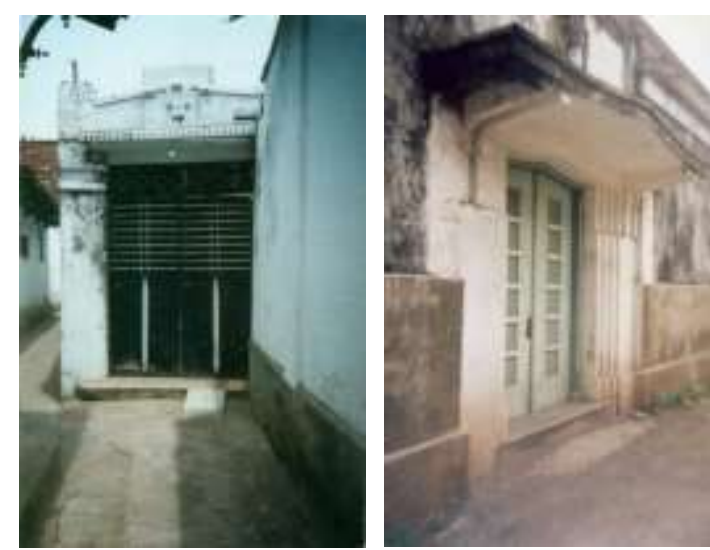

Gambar 3. Pintu Kilungan

(Sumber: Dokumentasi Pribadi, 2003)
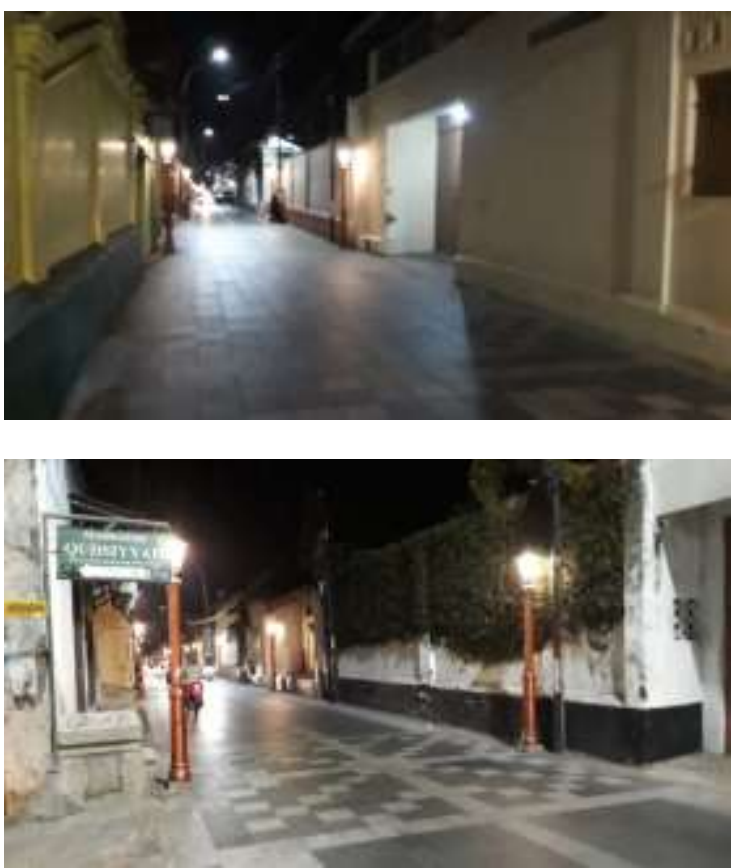

Gambar 4. Jalan Menara

(Sumber : Dokumentasi pribadi, 2019) 
Secara umum dalam rumah kilungan yang di dalamnya berupa rumah tradisional Kudus ada beberapa bangunan di dalam kilungan. Beberapa bangunan tersebut adalah rumah tradisional Kudus dan bangunan sisir (bangunan usaha) yang ada di depannya. Ada juga rumah kilungan yang mempunyai gotakan yaitu sebuah bangunan yang digunakan untuk memasak dan menyimpan bahan makanan.

Studi kasus 1 bangunan di dalam kilungan berbentuk rumah tradisional Kudus dengan gebyok dari kayu berukir dan sebagian bangunan sudah memakai batu bata. Rumah ini mempunyai susunan jogosatru, gedongan dan pawon. Pawon berada pada sebelah kanan (barat) dan digunakan untuk memasak sehari-hari. Kamar mandi ada pada bagian yang terpisah dari rumah yaitu arah depan pawon. Di sebelah selatan kamar mandi ada bangunan yang disebut sebagai gotakan yaitu sebuah bangunan memanjang yang hanya terdiri dari satu ruang dan digunakan untuk memasak besar. Pada gotakan inilah dahulu digunakan untuk memasak lem pada saat masih ada Pabrik Rokok.

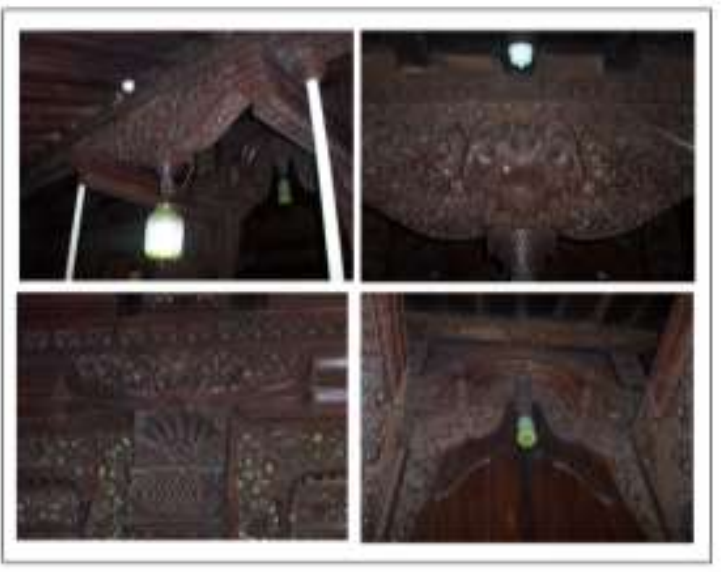

Gambar 5. Ukiran pada Jogosatru

(Sumber : Dokumentasi Jurusan Arsitektur FT UMJ, 2004)

Studi Kasus 1 mempunyai tembok kilungan masif dengan ketinggian $4 \mathrm{~m}$. Dahulu di dalam kilungan terdapat pondok dan kemudian pada tahun 1925 digunakan untuk pabrik rokok. Wawancara awal nara sumber untuk studi kasus 1 menyebutkan bahwa adanya tembok kilungan yang mengelilingi rumah tersebut adalah karena ajaran agama. Ajaran agama Islam yang dimaksud adalah masalah kesopanan dan tidak pamer, berkaitan dengan dua hal tersebut ajaran agama juga mengajarkan kepada orang agar tidak berbuat sesuatu yang menyebabkan orang lain berbuat jahat.
Rumah di dalam kilungan studi kasus 2 mempunyai susunan bangunan sama dengan studi kasus 1 namun tidak mempunyai gotakan. Bangunan sisir pada studi kasus 2 dari awal dibuatnya berbentuk bangunan biasa yang terbuat dari bahan batu bata. Sedangkan rumahnya keseluruhan dari kayu dan hanya lantainya saja yang tidak terbuat dari kayu. Pada tahun 1800-an bangunan sisir yang ada di depan rumah digunakan untuk membatik. Pada perkembangan berikutnya di tahun 1900an, bangunan sisir digunakan untuk merajang cengkeh. Pada tahun 1942 ada pelarangan penimbunan cengkeh sehingga usaha ini berakhir. Kilungan ini dibuat dengan alasan keamanan karena di bangunan sisir digunakan untuk menyimpan barang dagangan.

Pada studi kasus 3 dapat ditemukan bangunan rumah Kudus yang masih lengkap ukirannya. Pada ruang jogosatru dan pawon, kayu pembatas ruang semua masih berukir dengan dimensi dua. Bagian blandar yang digunakan pada jogosatru juga masih berukir. Hanya saja ukiran gedongan pada rumah ini sudah dijual. Rumah ini adalah rumah yang paling tua diantara kasus yang ada. Ketinggian lantai gedongan aslinya masih lebih tinggi daripada jogosatru. Pawon berada di sebelah barat dan berbatasan dengan jalan. Kilungannya dari dahulu sampai sekarang masih berbentuk masif dan hanya ada satu pintu utama. Alasan kilungan karena pengaruh dari arsitektur Cina dikemukakan oleh pemilik rumah berdasarkan wawancara yang menceritakan bahwa menurut cerita orang tua zaman dulu ketika Kyai The Ling Sing datang ke Kudus ada beberapa orang Cina dari Yunan yang mengikutinya kemudian mereka membuat rumah dengan diberi pagar tinggi seperti rumah mereka di Cina. Kemudian orang-orang Kudus mengikuti bentuk kilungan mereka. Tetapi kelanjutan cerita ini dan mengenai rumah-rumah orang Cina tersebut tidak dapat diketahui dengan pasti lokasinya.

Secara umum dapat dilihat bahwa rumah tradisional Kudus yang ada dalam kilungan masih menggunakan kayu sebagai material utama. Kayu digunakan pada bagian kudakuda, dinding, gebyok, tiang, blandar, dan bahkan sampai pintu jendela. Bagian yang tidak menggunakan material kayu adalah lantai dan penutup atap.

Atap yang digunakan adalah atap joglo pencu, yaitu bentuk atap joglo yang lebih menjulang dan bagian atasnya diberi hiasan. Jadi hiasan di rumah kilungan ada pada keseluran bagian 
rumah, bahkan sampai pada bancik yang menghubungkan jogosatru dengan gedongan.

Menurut Ashadi, bentuk atap joglo pencu di rumah tradisional Kudus menjulang ke angkasa, sebagai lambang kemakmuran. Semakin tinggi pencu akan menyiratkan pemiliknya semakin kaya. Begitupula dengan kerumitan ornamen, semakin rumit ornament, maka semakin kaya pemiliknya (Ashadi, 2010).

Rumah tradisional Kudus juga mempunyai konstruksi yang unik yaitu bisa dibongkar bagian-bagiannya tanpa merusak bagian tersebut. Berdasarkan pengamatan lapangan dan wawancara didapatkan bahwa sistem knock down tersebut memungkinkan rumah tradisional Kudus diukir bagian per bagiannya di tempat mengukir, kemudian dibawa ke lokasi untuk di pasang. Ada satu kunci yang digunakan untuk memasang dan membongkar rumah tradisional Kudus. Sehingga jika rumah tersebut akan diperbaiki bagiannya, bisa dilepas. Atau jika rumah tersebut akan dipindah, maka bagian dinding, tiang dan atap bisa dibongkar kemudian dipasang di tempat yang baru tanpa ada bagian yang rusak. Sedangkan untuk bagian bawah (lantai dan pondasi) pada umumnya permanen dan tidak dapat dipindah.

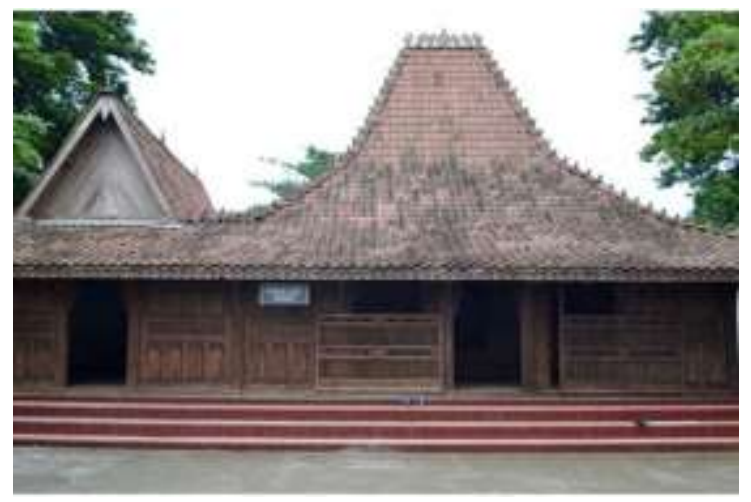

Gambar 6. Rumah Tradisional Kudus (Sumber : Mustofa, 2019)

Dalam wawancara juga didapatkan informasi bahwa rumah kilungan tersebut yang dibangun sekitar tahun 1800-an menggunakan rolaag batu bata untuk menumpu dinding rumahnya. Sedangkan dinding kilungan dibuat cukup tebal $30-40 \mathrm{~cm}$ dari bahan bata yang kuat.

Proses pembangunan rumah kilungan dimulai dari pembuatan pondasi dan lantai untuk bangunan utamanya yaitu rumah tradisional. Berdasar wawancara didapatkan informasi bahwa bangunan sumur dan kamar mandi yang berseberangan dengan bangunan utama dibuat terlebih dahulu sebelum bangunan rumahnya.

Sumur dan kamar mandi berada dalam 1 area yang biasanya berada di dekat pawon. Sumur yang buat berupa sumur terbuka yang dapat ditimba dan dilengkapi dengan dua buah kamar mandi yang berukuran cukup besar karena ada bak penyimpan air atau sering disebut kolam. Dari sumur, air ditimba kemudian dimasukkan ke kolam yang ada di dalam kamar mandi.

Sesudah pondasi dan lantai siap, maka dibangunlah rumah tradisional Kudus dengan merakit bagian-bagian yang sudah diukir sebelumnya.

\section{Identifikasi dan Deskripsi Aspek Budaya}

Pada identifikasi aspek budaya ditemukan ada kaitan antara bentuk rumah dengan keseharian masyarakat di Kota Lama Kudus. Aspek budaya dapat diamati melalui aktivitas berdagang dan mengaji, yaitu dua aktivitas yang sangat lekat dengan masyarakat asli Kota Lama Kudus.

Aktivitas mengaji terilhat dari keseharian masyarakat Kota Lama Kudus. Mengaji bisa dilakukan di masjid, di rumah kyai, atau di sekolah yang ada di dekat Menara Kudus. Dahulu di tahun 1980-an studi kasus 1 digunakan juga sebagai tempat mengaji anakanak. Anak-anak mengaji memenuhi ruang jogosatru. Pada tahun yang sama, rumah kilungan ini juga menyediakan tempat mondok seperti pondok pesantren untuk penghafal Al Qur'an.

Aktivitas mengaji juga dapat ditemukan pada studi kasus 3 hingga sekarang ini. Ada beberapa santri putri yang mondok disini dan mereka menempati bangunan sisir. Aktivitas perdagangan dapat ditemukan pada semua studi kasus mulai dari awal dibangunnya karena itulah rumah kilungan mempunyai bangunan sisir sebagai bangunan yang digunakan sebagai tempat usaha.

Dapat ditafsirkan bahwa mengaji dan berdagang sudah menjadi aktivitas yang melekat dan dilakukan secara turun menurun. Dengan jenis usaha yang bisa berubah-ubah sesuai dengan tuntutan zaman.

Masyarakat Kota Lama Kudus juga terkenal dengan perkawinan yang masih terikat hubungan kerabat. Sehingga dapat ditemukan 
masyarakat Kota Lama Kudus masih terikat kerabat antara satu dengan yang lain.

Aspek budaya dapat dilihat juga pada bentuk fisik rumah kilungan yang mempunyai pintu penghubung ke tetangganya walaupun tidak mempunyai hubungan kekerabatan. Rumah kilungan hampir semua mempunyai pintu penghubung kea rah tetangganya. Hal ini membuktikan walaupun tidak ada hubungan kekerabatan dengan tetangga namun memiliki hubungan baik. Sehingga untuk berinteraksi dengan tetangga tidak perlu melalui pintu utama rumahnya.

Contohnya pada studi kasus 1 , mempunyai pintu penghubung dengan tetangga yang disebelah utara, barat dan timurnya melalui pintu kecil berukuran $90 \mathrm{~cm}$. pintu penghubung dengan tetangga sebelah utara diakses melalui pawon. Pintu penghubung dengan tetangga sebelah barat diakses melalui pawon, dan pintu penghubung dengan tetangga sebelah timur dapat diakses melalui latar.

\section{Aspek Lingkungan pada Rumah Kilungan}

Aspek lingkungan pada ranah fisik dan abstrak berkaitan dengan dimana bangunan itu berada. Rumah kilungan berada di Kota Lama Kudus, sebuah kota yang disebut dengan kota kretek karena maraknya industri rokok sejak masa tahun 1900 hingga sekarang. Kota Kudus juga dikenal sebagai kota santri karena banyaknya pesantren yang ada di Kota ini, terutama di kawasan kota lama Kudus.

Aspek lingkungan dapat dilihat juga pada arah hadap bangunan utama dalam rumah kilungan. Rumah tradisional Kudus yang ada di dalam rumah kilungan disebut sebagai bangunan utama disebabkan ada bangunan lain yang berada di dalam kilungan. Bangunan lain tersebut adalah gotakan dan bangunan sisir.

Arah hadap yang terpenting dalam rumah kilungan adalah arah hadap bangunan utamanya. Sedangkan bangunan lain akan mengikuti bangunan utama. Antara bangunan utama dengan bangunan sisir akan diberi jeda ruang terbuka yang merupakan bagian penting dalam rumah kilungan. Ruang terbuka itu yang dijadikan pusat dalam lingkup mikro rumah tinggal dan terwujudkan dalam latar.

Rumah di dalam kilungan yang menghadapkan bangunan utamanya ke arah latar, ternyata tidak hanya menghadapkan bangunan utamanya saja tetapi juga bangunan-bangunan lain yang ada di dalam kilungan di hadapkan ke latar tersebut. Dari tiga kasus tersebut ditemukan kesamaan pola yaitu rumah aslinya tradisional Kudus dan menghadap selatan, mempunyai lahan yang cenderung memanjang utara-selatan, mempunyai orientasi bangunan ke arah latar dan mengusahakan pintu masuk dari arah samping. Latar yang dijadikan arah hadap bangunan utama adalah latar ngarep.

Arah hadap bangunan ke selatan mempunyai banyak arti, antara lain berkaitan dengan kondisi lingkungan sekitarnya. Rumah yang menghadap selatan akan mendapatkan sinar matahari yang cukup sepanjang hari. Sesuai juga dengan teori dalam arsitektur yang mengoptimalkan sisi terpanjang bangunan di sisi selatan atau utara. Karena di dua sisi tersebut dapat dibuat bukaan secara maksimum. Rumah di dalam kilungan sudah mengaplikasikan teori ini dari awal berdirinya sekitar tahun 1700-1800an. Dapat dilihat bahwa sisi bangunan terpendek pda bangunan utama diletakkan di barat dan timur. Kemudian di sisi tersebut dibuat bukaan jendela dan pintu dalam ukuran yang lebih kecil.

Pembahasan lain berkaitan dengan aspek lingkungan adalah orientasi bangunan dan elemen yang dijadikan arah orientasi

Pada studi kasus 1 bangunan rumah tinggal, kamar mandi, sumur, dan gotakan semuanya menghadap ke latar ngarep yang ada di depan rumah tinggal dan berada di tengah lahan kilungan. Sehingga penunjukan arah depan bangunan tersebut adalah arah latar, jadi keseluruhan bangunan mempunyai orientasi ke arah halaman/latar. Pada studi kasus 1 ini ruang terbuka dalam kilungan hanya ada pada bagian tengah kilungan yaitu berupa halaman/latar yang menjadi orientasi bangunan-bangunan yang ada di rumah tersebut.

Sebenarnya pada bagian belakang rumah ini ada lorong yaitu ruang sisa antara rumah ini dengan rumah tetangganya selebar 1,5 meter yang digunakan untuk memasukkan cahaya dan udara dari sisi utara. Lorong atau lurung ini tidak disebut sebagai ruang terbuka pada kilungan ini.

Penjelasan yang hampir serupa didapatkan pada studi kasus 2 yang berada di dalam kilungan dan berisi bangunan sisir, rumah tinggal, kamar mandi dan sumur, latar serta kebonan. Rumah tinggal terletak di sebelah utara dan menghadap ke selatan yaitu pada 
latar ngarep yang ada didepan rumahnya. Bangunan sisir menghadap ke utara yaitu menghadap pada latar yang ada didepannya, begitupula dengan kamar mandi dan sumur. Rumah Ini tetap mempertahankan latar ngarep yang ada di tengah antara bangunan rumah tinggal dan bekas bangunan sisir. Pada kasus ini yang disebut sebagai ruang terbuka merupakan ruang yang ada di antara bangunan utama disebelah utara dengan bangunan sisir, kamar mandi, sumur dan kebon.

Pada studi kasus 3 ruang terbuka yang berupa latar ngarep ada di antara rumah tinggal dan bangunan sisir, kamar mandi, pawon masak, sumur dan bangunan sisir. Rumah kilunganini seperti pada umumnya, yaitu mempunyai orientasi pada latar ngarep yang ada di antara bangunan rumah tinggal dan bangunan sisir.

Dari beberapa kasus di atas, latar adalah ruang terbuka yang dapat langsung dilihat ketika seseorang memasuki kilungan tersebut. Pada studi kasus 1 dan 3 lahan memanjang utara-selatan dan rumah ada pada sebelah utara sedangkan pintu masuk dari arah samping yaitu arah barat atau timur. Sehingga begitu ada seseorang yang membuka pintu utama maka yang terlihat pertama kali adalah latar. Hal inilah yang merupakan penjelas aspek lingkungan dalam ranah abstrak. Karena menjadikan latar sebagai pusat dalam rumah kilungan maka penunjukan depan adalah arah latar, begitupula dengan keberadaan pintu masuk kilungan diarahkan ke latar, bukan ke bangunan utama. Semakin mendekati latar ngarep maka itulah arah depan dan semakin menjauhi latar ngarep maka itulah arah belakang. Penunjukan ini sudah melekat dalam benak penghuni rumah tetapi jarang sekali diungkapkan.

Penempatan pintu masuk kilungan dari arah samping dan menuju ke latar dapat dimaknai bahwa rumah kilungan mempunyai privasi yang tinggi. Ketika ada orang masuk ke kilungan, tidak dapat langsung menuju rumah namun harus melewati latar terlebih dahulu.

\section{KESIMPULAN}

Arsitektur vernakular memiliki sifat lokalitas yang bermakna menyesuaikan iklim lokal, menggunakan teknik dan material lokal, dipengaruhi oleh aspek sosial, budaya, dan ekonomi masyarakat setempat.

Rumah Kilungan Kudus mempunyai susunan jogosatru, gedongan dan pawon. Keseluruhan rumah terbuat dari kayu. Menurut sejarah, kilungan dibuat dengan alasan keamanan untuk melindungi barang dagangan yang tersimpan di dalam rumah. Kilungan ini pengaruh dari arsitektur Cina.

Dalam Rumah Kilungan Kudus, latar sebagai elemen perwujudan dari 'pusat' atau orientasi permukiman berupa ruang terbuka yang dapat langsung terlihat ketika seseorang memasuki kilungan.

Rumah tradisional Kudus yang berada di dalam kilungan masih menggunakan kayu sebagai material utama. Material kayu digunakan pada kuda-kuda, dinding, gebyok, tiang, blandar, pintu dan jendela, kecuali pada lantai dan penutup atap. Hiasan juga terdapat pada keseluran bagian rumah sebagai identitas kekayaan pemiliknya.

Pada aspek budaya ditemukan keterkaitan antara bentuk rumah dengan aktivitas masyarakat yaitu mengaji dan berdagang. Aspek budaya juga terlihat pada bentuk fisik rumah kilungan yang mempunyai pintu penghubung dengan tetangga meskipun tidak terdapat hubungan kekerabatan.

Pada aspek lingkungan, kota kudus dikenal sebagai kota santri, bangunan utama dalam rumah kilungan menghadap selatan, mempunyai lahan memanjang utara-selatan, mempunyai orientasi ke arah latar dan mengusahakan pintu masuk dari arah samping. Penempatan pintu masuk kilungan dari arah samping dan menuju ke latar ini dapat dimaknai bahwa rumah kilungan mempunyai privasi yang tinggi.

\section{DAFTAR PUSTAKA}

Anisa. (2004). Rumah di dalam Kilungan di Kota Lama Kudus. NALARs Jurnal Arsitektur, 3(1).

Anisa. (2018). Karakteristik Arsitektur Di Kota Lama Kudus. NALARs Jurnal Arsitektur, $17(2)$.

Ashadi. (2010). Jejak Keberadaan rumah Tradisional Kudus. NALARs Jurnal Arsitektur, 9(2).

Bagaskara, Y. V. M., \& Yusran, Y. A. (2018). Struktur Hasil Translokasi Bangunan Vernakular Jawa Timur di Kampoeng Djawi Wonosalam. Jurnal RUAS, 16(2), 49-60.

Mentayani, I. ... Muthia, P. R. (2017). Menggali Makna Arsitektur Vernakular: Ranah, Unsur, dan Aspek-Aspek Vernakularitas. Prosiding Temu IImiah IPLBI, I109-I116. 
https://doi.org/10.32315/ti.6.i109

Mustofa, A. (2019). Ini Alasan Tim Ahli Cagar Budaya Kaji Ulang Rumah Adat Kudus.

Rengkung, J. (2011). Arsitektur Vernakular Rumah Tinggal Masyarakat Etnik Minahasa. Media Matrasain, 8(3), 108120.

Sani, A. A. ... Rukayah, R. S. (2015). Bentuk Dan Proporsi Pada Perwujudan Arsitektur Vernakular Bugis. Jurnal Teknik Sipil Dan Perencanaan, 17(2), 99-110.

https://doi.org/10.15294/jtsp.v17i2.6885

Sumintardja, D. (1981). Kompendium Sejarah Arsitektur. Bandung: Penerbit Yayasan Lembaga Penyelidikan Masalah Bangunan.

Tarigan, R. (2016). Arsitektur Vernakular Berbasis Arsitektur Tradisional: Menuju Arsitektur Lokal Yang Berkelanjutan. Tesa Arsitektur, 14(1), 23-32.

Wikantari, R. R., \& Narumi, K. (1999). Preserving Wooden Traditional Houses Through Community Empowermwnt: the Case of an Historic Area of Kudus, Indonesia. Vernacular Settlement, 202. Jakarta: The Faculty of Engineering University of Indonesia.

Wiranto. (1999). ARSITEKTUR VERNAKULAR INDONESIA: Perannya Dalam Pengembangan Jati Diri. DIMENSI (Journal of Architecture and Built Environment), 27(2), 15-21. 
